\section{Checklist of Ericaceae in Tuensang District of Nagaland, India with special reference to Mt. Saramati}

\section{S. Panda}

Post Graduate Department of Botany, Darjeeling Govt. College, Darjeeling, West Bengal 734101, India

Email: bgc.panda@gmail.com

During the course of revisionary work on Indian Ericaceae carried out at the Central National Herbarium (CAL) under the "Flora of India Project" (1999-2004), an attempt was made to survey the inaccessible and dense virgin flora of Mt. Saramati besides other parts of Tuensang District. Earlier under the leadership of N.L. Bor, an expedition team consisting of F. KingdonWard, J.H. Hutton and B.S. Hartland surveyed a part of Tuensang District including Mt. Saramati in 1935 (Bor 1936). After six decades, T.M. Hynniewta (1994) surveyed a part of this district including the mountain. Only a few ericaceous taxa (12 taxa) were enumerated earlier mostly confined to the vicinity of Mt. Saramati. A team of six members, including the author, from the Botanical Survey of India, Eastern Circle, Shillong surveyed different parts of Tuensang District including Mt. Saramati during March-April,

Date of publication (online): 26 December 2012

Date of publication (print): 26 December 2012

ISSN 0974-7907 (online) | 0974-7893 (print)

Editor: P. Lakshminarasimhan

Manuscript details:

Ms \# 02939

Received 09 September 2011

Final received 09 May 2012

Finally accepted 15 October 2012

Citation: Panda, S. (2012). Checklist of Ericaceae in Tuensang District of Nagaland, India with special reference to Mt. Saramati. Journal of Threatened Taxa 4(15): 3454-3461.

Copyright: () S. Panda 2012. Creative Commons Attribution 3.0 Unported License. JoTT allows unrestricted use of this article in any medium for nonprofit purposes, reproduction and distribution by providing adequate credit to the authors and the source of publication.

Acknowledgements: The author is grateful to Dr. M. Sanjappa, ex-Director Botanical Survey of India for guidance and providing all facilities during field survey to Tuensang district including Saramati Mt. in 2003. Thanks are also due to Mr. Chuwayuti Cheng, Extra-Assistant Commissioner, Kiphire for his kind permission to survey and providing one Amakhangese guide as interpretator, and to Dr. A.A. Mao, Jt. Director, Arunachal Field Station, Itanagar (then Scientist C at ASSAM) and Dr. T.M. Hynniewta, In-Charge of ASSAM for their all sorts of help for Saramati visit.

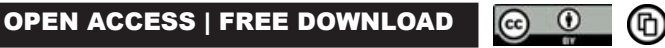

2003 and enumerated 30 taxa of Ericaceae, of which 25 were collected from Mt. Saramati.

Mt. Saramatilies approximately between $26^{0} 2^{\prime}-26^{0} 7^{\prime} \mathrm{N} \& 97^{0} 6^{\prime}-97^{0} 13^{\prime} \mathrm{E}$ with an area of about $200 \mathrm{~km}^{2}$ and altitudes ranging from 2400 $3826 \mathrm{~m}$ on the Barail range in Tuensang District under Kiphire subdivision of Nagaland. Mt. Saramati harbours both temperate as well as Himalayan alpine vegetation (2400-3841 m). Alpine vegetation starts at the base camp area of Mt. Saramati (3000m) and extends up to the peak $(3841 \mathrm{~m})$. Although Changkija \& Kumar (1997) mentioned that "the alpine vegetation is met with at high altitudes in ridges of Saramati range, which remains covered with snow for a major part of the year from October to April". The journey from Kohima (state capital) to Kiphire (subdivision of Tuensang District), took about 10 hours by jeep $(254 \mathrm{~km})$ and from Kiphire to Penkim Village through Pungro (Circle H.Q.) and Salumi by jeep through a narrow and muddy non-metal road took one day (about $62 \mathrm{~km})$. From Penkim Village $(2100 \mathrm{~m})$ it took three days of trekking to reach the peak of Mt. Saramati through Thanamier Village (Fig. 1). A part of Mt. Saramati falls within Myanmar. Besides Mt. Saramati, other places in Tuensang District like Kiphire, Lothar, Pungro, Salumi, Penkim, Fakim Wildlife Sanctuary and Thanamier were also surveyed.

Climate of Mt. Saramati and its vicinity: During summer, the average rainfall is between 200-250 $\mathrm{cm}$ and the bulk of precipitation is received through the south-west monsoon. The temperature varies between $10-20{ }^{\circ} \mathrm{C}$. In winter, the climate is generally dry with low precipitation. The temperature varies between $10-5{ }^{\circ} \mathrm{C}$ and heavy snowfall occurs at higher elevations.

Topography: Mt. Saramati lies on the Barail range which flanks the boundary with Myanmar. The area is entirely hilly and the terrain is one of the most rugged with successive hills of varying heights (Image 1A).

The family Ericaceae Juss. comprises ca. 117 genera and 3850 species, cosmopolitan except deserts, usually montane in tropics (Mabberley 2008). A total of 13 genera and ca. 200 species occur in India (Panda 2008). The family is represented by nine genera and 37 species in Nagaland (Panda 2008). In this paper, the currently accepted names, habitat, available field data, 


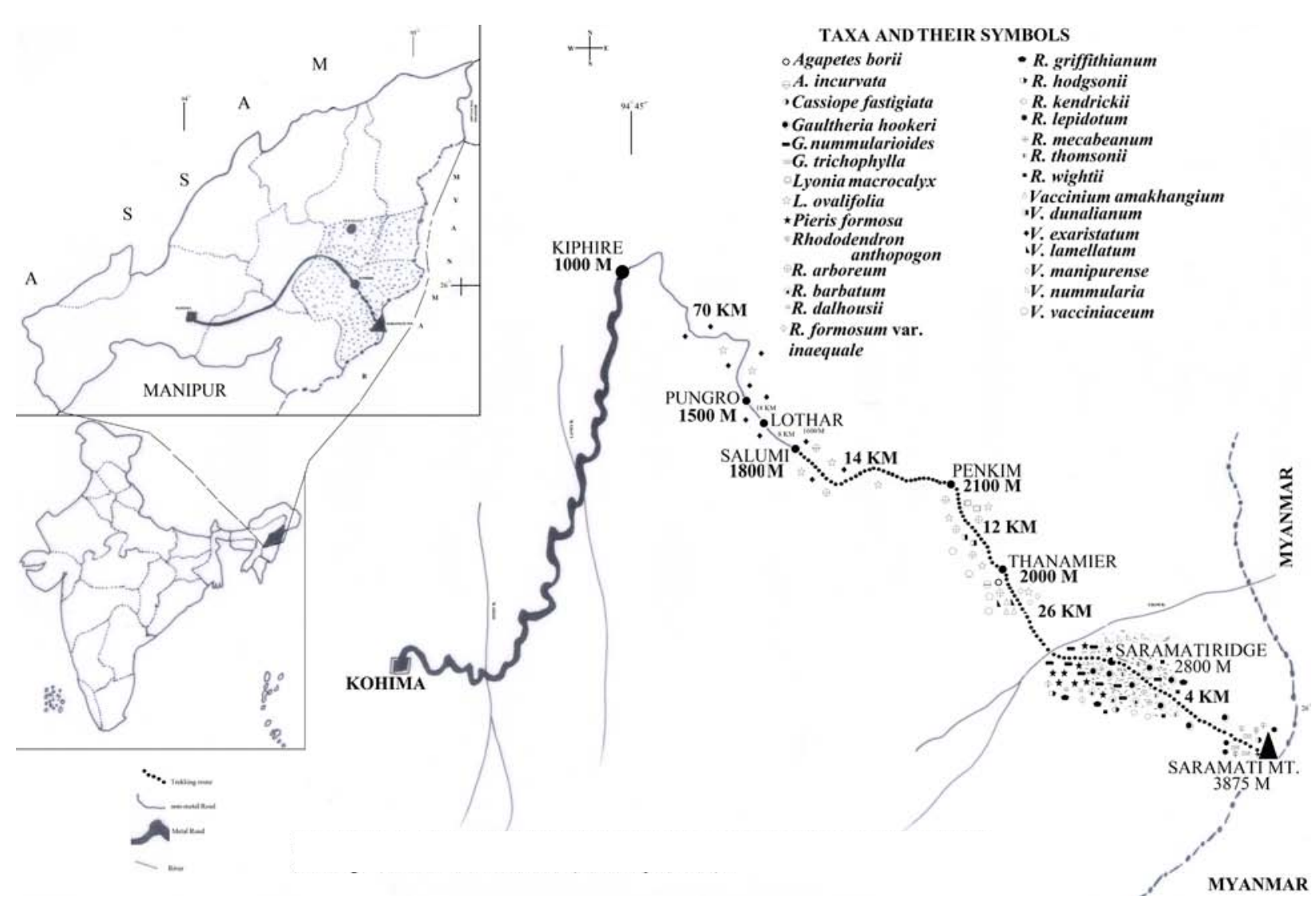

Figure 1. Field study areas and collection sites in Tuensang District (Kiphire to Saramati Mt.) showing detailed distribution of taxa (March-April 2003)

distribution, threats, relative abundance and specimens examined of 30 taxa belonging to Ericaceae recorded from Tuensang District along with images of live and herbarium specimens of some taxa are provided for easy identification in the field. The enumeration includes, one new taxon, two new records from India and three new distributional records for Nagaland. Of the 30 taxa enumerated, five are endemic to Naga Hills and two are endemic to Naga Hills and Eastern Himalaya. Ten taxa are classified as threatened (Anonymous 2009; Vie et al. 2009) due to rapid habitat degradation as a result of natural weathering and rising jhum cultivation practices among different Naga ethnic groups (Image 1B).

\section{Enumeration}

A. Subtropical region (1100-1700): It includes Kiphire, Pungro Circle including Salumi areas.

(i) Lyonia ovalifolia (Wall.) Drude: Corolla greywhite, tubular. Habit—stout erect shrub to treelet up to $3 \mathrm{~m}$ high. Habitat - growing along rocky slopes. Field status - common.
Distribution: India (Himalaya and northeastern India excluding Tripura), Pakistan, Nepal, Bhutan, Bangladesh, western China, Taiwan, northern Myanmar, Thailand, Malesia and Japan.

Specimens examined: 30.iii.2003, Kiphire to Pungro, 1600m, coll. S. Panda s.n. (CAL); 31.iii.2003, near Thanamier Village, Tuensang District, $1800 \mathrm{~m}$, coll. S. Panda 30861 (CAL) (Image 2B).

(ii) Vaccinium exaristatum Kurz: Corolla white to pinkish. Habit - stout erect shrub to treelet up to $5 \mathrm{~m}$ high. Habitat — growing along rocky slopes. Field status-common.

Distribution: India (northeastern India: Nagaland, Manipur and Mizoram), China, Myanmar, Thailand, Laos and Vietnam. Newly recorded from India from Naga Hills (Image 3F).

Specimens examined: 30.iii.2003, near Pungro village, Tuensang District, 1300m, S. Panda 30857 (CAL). Newly recorded from India from Naga Hills (Image 3F).

B. Subtropical-temperate mixed region (1700-2300 

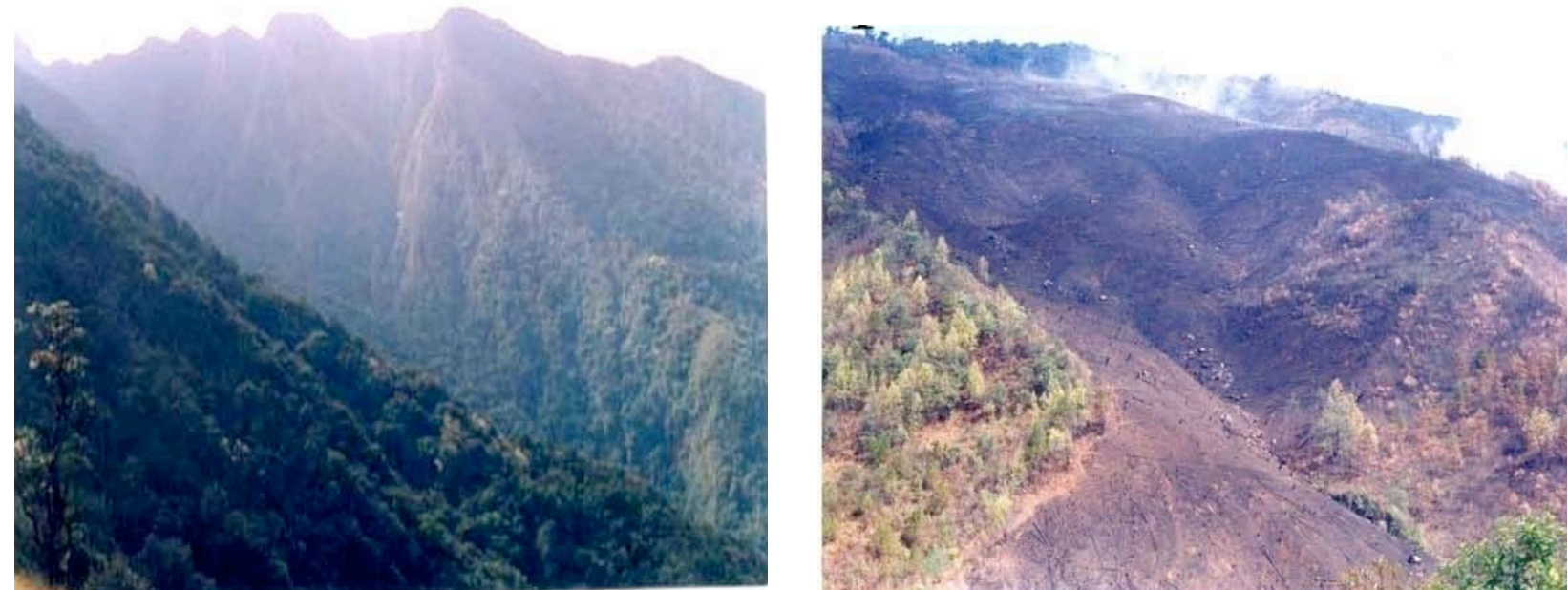

Image 1. A - View of Saramati Mountain Peak from the Ridge; B - Jhum cultivation practice by Amakhangese Nagas at Thanamier.

$\underline{\mathrm{m})}$ : It includes Penkim, lower part of Fakim Wildlife Sanctuary and Thanamier areas.

(iii) Agapetes borii Airy Shaw: Corolla lemon yellow. Habit — dwarf bushy shrub up to $0.5 \mathrm{~m}$ high. Habitat-growing as epiphyte on Rhododendron arboretum. Field status - threatened (mass cutting of forest trees due to jhum cultivation practices).

Distribution: Endemic to Naga Hills in India (northeastern India: Nagaland and Manipur).

Specimens examined: 01.iv.2003, above Thanamier Village, ca. 2200m, coll. S. Panda s.n. (CAL).

(iv) A. incurvata (Griff.) Sleumer: Corolla light green. Habit-dwarf shrub up to $0.3 \mathrm{~m}$ high. Habitat-growing as epiphyte on Quercus incana. Field status - threatened (mass cutting of forest trees due to jhum cultivation practices).

Distribution: India (eastern Himalaya: Sikkim, Arunachal Pradesh; northeastern India: Meghalaya and Nagaland), Nepal, Bhutan, Bangladesh and China (southeastern Xizang). Newly recorded from Nagaland.

Specimens examined: 01.iv.2003, above Thanamier Village, ca. 2100m, coll. S. Panda s.n. (CAL).

(v) Lyonia macrocalyx (J. Anthony) Airy Shaw: Flowers not seen, fruits green. Habit-stout erect shrub to treelet up to $2 \mathrm{~m}$ high. Habitat-growing along rocky slopes. Field status - threatened (only two small populations were observed).

Distribution: India (eastern Himalaya: Arunachal Pradesh and northeastern India: Nagaland) western China and N Myanmar. Newly recoded from India as well as from Naga Hills (Image 2C).

Specimens examined: 31.iii.2003, Penkim to Thanamier Village, Tuensang District, $1800 \mathrm{~m}$, coll. S. Panda 30858.

(vi) Rhododendron arboreum Sm.: Corolla blood red. Habit - treelet up to $2 \mathrm{~m}$ high. Habitat - growing along rocky slopes. Field status_common.

Distribution: India (Arunachal Pradesh, Meghalaya, Nagaland, Manipur and Mizoram), China (Yunnan, Guizhou), northern Myanmar and northern Thailand.

Specimens examined: 31.iii.2003, Penkim to Thanamier, ca. 2000m, coll. S. Panda 30856 (CAL). (Image 2D).

(vii) Vaccinium vacciniaceum (Roxb.) Sleumer: Corolla light green to light yellow. Habit-stout erect shrub up to $1 \mathrm{~m}$ high. Habitat - epiphytic on old tree trunks of Quercus incana. Field status-Common.

Distribution: India (eastern Himalaya: Darjeeling in West Bengal, Sikkim and Arunachal Pradesh and northeastern India: Meghalaya, Nagaland, Manipur and Mizoram), Nepal, Bhutan, southwestern China and northern Myanmar.

Specimens examined: 01.iv.2003, Thanamier Village, 2000m, coll. S. Panda 30865 (CAL) (Image 3E).

(viii) $\boldsymbol{V}$. manipurense (Watt ex Brandis) Sleumer: Corolla light pink, immature fruits green. Habitstout erect shrub up to $1 \mathrm{~m}$ high. Habitat - growing as epiphyte on Quercus sp. Field status - threatened.

Distribution: Endemic to India (eastern Himalaya: Arunachal Pradesh and northeastern India: Meghalaya, 
Nagaland, Manipur), Nepal, Bhutan, southwestern China and northern Myanmar.

Specimens examined: 01.iv.2003, above Thanamier Village, Tuensang District, 2300m, coll. S. Panda 30864 (CAL) (Image 3B).

(ix) $\boldsymbol{V}$. dunalianum Wight: Flowers not seen, fruits berries, black. Habit—pendent dwarf shrub up to $1 \mathrm{~m}$ high. Habitat - growing as epiphyte on Quercus sp. Field status - common.

Distribution: India (eastern Himalaya and northeastern India excluding Tripura and Mizoram), Nepal, Bhutan, western China, Taiwan, northern Myanmar and Vietnam.

Specimens examined: 31.iii.2003, Penkim to Thanamier, 2000m, coll. S. Panda s.n. (CAL).

C. Temperate region $(2300-2800 \mathrm{~m})$ : It includes $7 \mathrm{~km}$ away from Thanamier Village up to Saramati ridge.

(x) Gaultheria hookeri C.B. Clarke: Corolla urceolate, pinkish. Habit-dwarf bushy shrub up to $0.5 \mathrm{~m}$ high. Habitat-growing along rocky slopes. Field status_-common.

Distribution: India (eastern Himalaya: Darjeeling in West Bengal, Sikkim and Arunachal Pradesh and northeastern India: Nagaland), Nepal, Bhutan, southwestern China and northern Myanmar. Newly recorded from Naga Hills (Image 2A).

Specimens examined: 02.iv.2003, Saramati ridge, Tuensang District, 2800m, S. Panda 30872 (CAL).

(xi) G. nummularioides D. Don: Flowers not seen, fruits capsule, black. Habit - mat forming procumbent dwarf shrub up to $0.2 \mathrm{~m}$ high. Habitat - growing along rocky slopes and ridges. Field status - common.

Distribution: India (Himalayas and northeastern India: Meghalaya, Nagaland and Manipur), Pakistan, Nepal, Bhutan, western China, northern Myanmar, Sri Lanka and Malesia.

Specimens examined: 02.iv.2003, Saramati Ridge, 2800m, S. Panda 30874 (CAL).

(xii) Pieris formosa (Wall.) D. Don: Corolla urceolate, snow white. Habit-stout erect shrub to treelet up to $5 \mathrm{~m}$ high. Habitat - growing along rocky slopes. Field status - common.

Distribution: India (eastern Himalaya: Darjeeling in West Bengal, Sikkim, Arunachal Pradesh and northeastern India: Meghalaya, Nagaland and Manipur), Nepal, Bhutan, southwestern China, northern Myanmar and Vietnam.

Specimens examined: 02.iv.2003, Saramati Ridge, 2700-3200 m, coll. S. Panda 30868 (CAL).

(xiii) Rhododendron wattii Cowan: Corolla rose red to pink. Habit - treelet up to $1 \mathrm{~m}$ high. Habitatgrowing along rocky slopes. Field status - threatened (only three plants were observed throughout Mt. Saramati).

Distribution: Endemic to Naga Hills in India (Nagaland and Manipur).

Specimens examined: 01.iv.2003, Saramati ridge, 2600m, coll. S. Panda s.n. (CAL) (Image 2E).

(xiv) R. thomsonii Hook. f.: Corolla deep crimson to blood red. Habit - treelet up to $2 \mathrm{~m}$ high. Habitatgrowing along rocky slopes. Field status - common.

Distribution: India: eastern Himalaya (Sikkim, Arunachal Pradesh) and northeastern India (Nagaland), Bhutan and southwestern China.

Specimens examined: 01.iv.2003, Saramati ridge, 2600m, coll. S. Panda 30898 (CAL).

(xv) R. hodgsonii Hook. f.: Corolla rose-purple. Habit-treelet up to $4 \mathrm{~m}$ high. Habitat-growing along rocky slopes. Field status-common.

Distribution: India: eastern Himalaya (Sikkim, Darjeeling in West Bengal and Arunachal Pradesh) and northeastern India (Nagaland), Nepal, Bhutan and western China.

Specimens examined: 02.iv.2003, Saramati ridge proper, 2600m, coll. S. Panda 30899 (CAL).

(xvi) R. formosum Wall. var. inaequale (Hutch.) Cullen: Corolla white flushed pink. Habit - treelet up to $1 \mathrm{~m}$ high. Habitat-growing along rocky slopes. Field status - threatened (two small populations were observed along Saramati ridge and its vicinity).

Distribution: Endemic to India (eastern Himalaya: Arunachal Pradesh and northeastern India: Meghalaya, Nagaland and Manipur).

Specimens examined: 02.iv.2003, Saramati ridge proper, 2600m, coll. S. Panda s.n. (CAL).

(xvii) Vaccinium amakhangium Panda \& Sanjappa: Corolla urceolate, light green. Habitdwarf shrub up to $0.5 \mathrm{~m}$ high. Habitat-growing as epiphyte on Quercus incana. Field status - threatened (mass cutting of large trees due to jhum cultivation practices). This is a newly described species (Panda \& Sanjappa 2008) (Image 3C).

Distribution: Endemic to Nagaland in India.

Specimens examined: 01.iv.2003, above Thanamier 

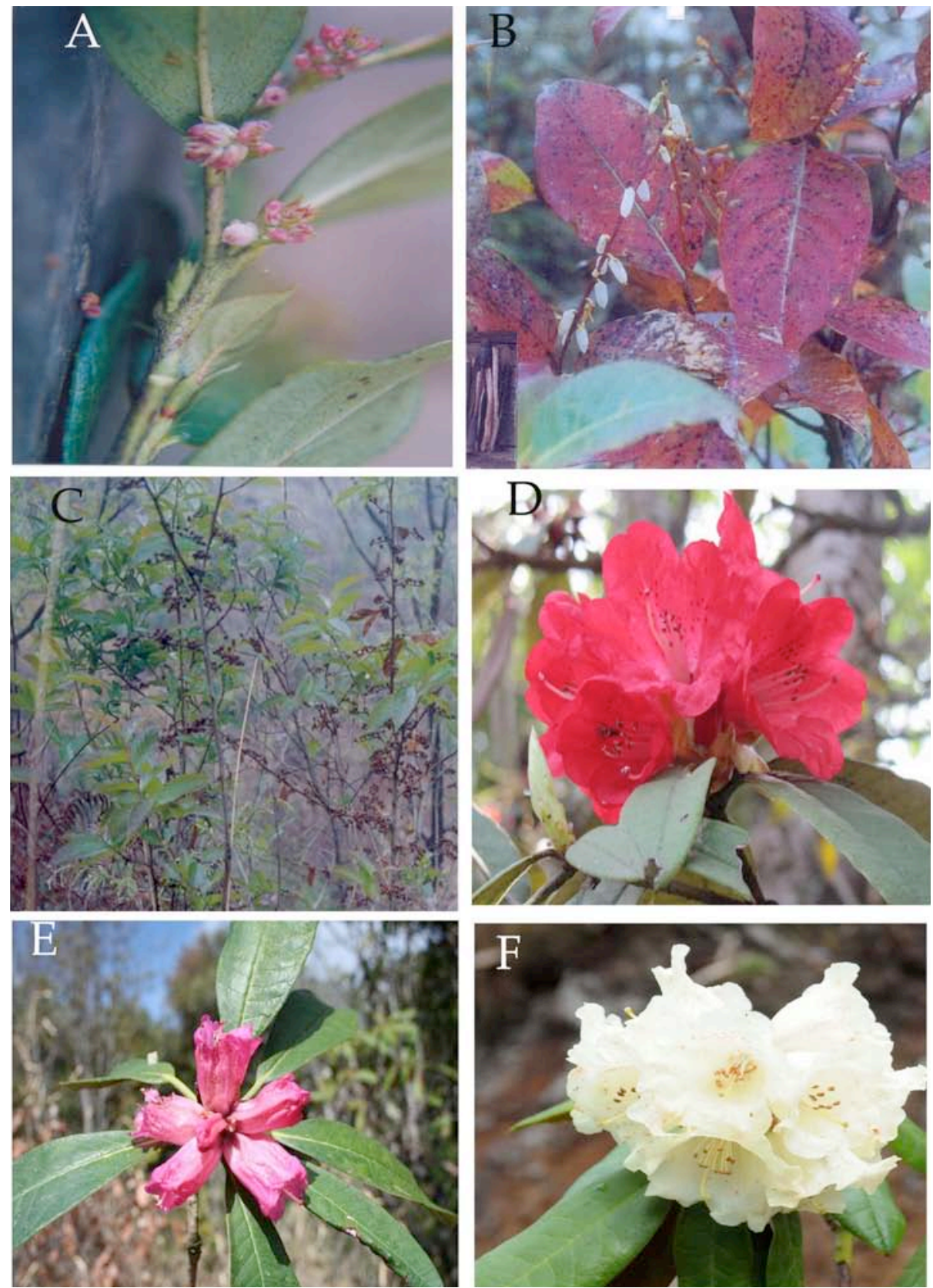

Image 2. A - Gaultheria hookeri; B - Lyonia ovalifolia; C - L. macrocalyx; D - Rhododendron arboreum; E - R. wattii; F - R. wightii

Village, on the way to Mt. Saramati, 2300m, coll. S. Panda 30862 (CAL).

(xviii) V. lamellatum P.F. Stevens: Corolla tubulourceolate, whitish-green. Habit-stout and erect dwarf shrub up to $0.5 \mathrm{~m}$ high. Habitat - grown as epiphytic on Quercus incana. Field status - threatened (mass cutting of large trees due to jhum cultivation practices).

Distribution: Endemic to Naga Hills in India (Nagaland and Manipur). Newly recorded from
Nagaland (Image 3A).

Specimens examined: 01.iv.2003, above Thanamier Village, Tuensang District, 2300m, coll. S. Panda 30863 (CAL).

(xix) V. retusum (Griff.) Hook. f. ex C.B. Clarke: Corolla urceolate, light pink. Habit—stout erect dwarf shrub up to $1 \mathrm{~m}$ high. Habitat - growing along moist rocky slopes. Field status - common.

Distribution: India (eastern Himalaya and northeastern India: Nagaland and Manipur), Nepal, 

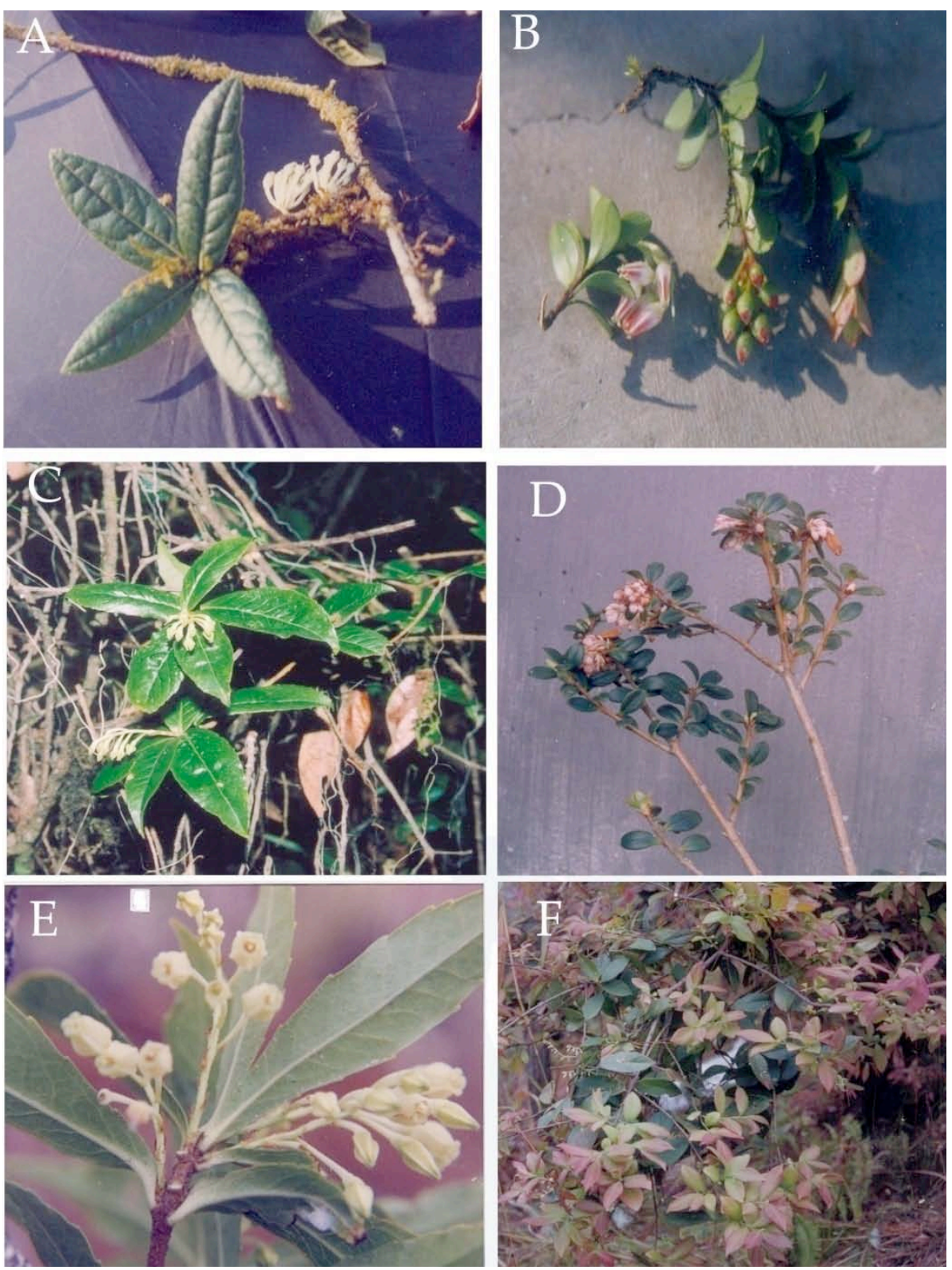

Image 3. A - Vaccinium lamellatum; B - V. manipurense; C - V. amakhangium; D - V. retusum; E - V. vacciniaceum; F - V. exaristatum

Bhutan, southwestern China and northern Myanmar.

Specimens examined: 02.iv.2003, Saramati ridge proper, 2600m, coll. S. Panda s.n. (CAL) (Image 3D).

(xx) V. nummularia Hook. f. \& Thomson: Corolla urceolate, pinkish. Habit—stout pendent dwarf shrub up to $1 \mathrm{~m}$ high. Habitat — growing along moist rocky slopes. Field status - common.

Distribution: India (Sikkim, West Bengal and Arunachal Pradesh and Nagaland), Nepal, Bhutan, southwestern China, and northern Myanmar.

Specimens examined: Saramati ridge, 2800m, 02.iv.2003, coll. S. Panda 30875 (CAL).
D. Border of temperate and sub-alpine region up to $3300 \mathrm{~m}$ : It includes the whole Saramati ridges including the base camp area.

(xxi) $\boldsymbol{R}$. wightii Hook. f.: Corolla yellow with purple flecks on the posterior lobe and blotch at base. Habit - treelet up to $4 \mathrm{~m}$ high. Habitat - growing along moist rocky slopes. Field status - threatened (4 plants observed along ridge and its vicinity).

Distribution: India: Eastern Himalaya (Sikkim and Arunachal Pradesh) and northeastern India (Nagaland), Nepal, Bhutan and western China.

Specimens examined: Saramati ridge, $2650 \mathrm{~m}$, 
02.04.2003, S. Panda s.n. (CAL) (Image 2F).

(xxii) R. barbatum Wall. ex G. Don: Corolla blood red with darker nectar pouches at base. Habit-treelet up to $1 \mathrm{~m}$ high. Habitat - growing along moist rocky slopes. Field status - common.

Distribution: India: Himalaya (Uttarakhand, Sikkim, Darjeeling in West Bengal, Arunachal Pradesh) and northeastern India (Nagaland), Nepal, Bhutan and southwestern China.

Specimens examined: 02.iv.2003, Saramati ridge, 2650m, coll. S. Panda s.n. (CAL).

(xxiii) R. maecabeanum (Watt ex Balf. f.) Cullen: Corolla lemon yellow. Habit - treelet up to $3 \mathrm{~m}$ high. Habitat-growing along moist rocky slopes. Field status-common.

Distribution: Endemic to Naga Hills in India (Nagaland and Manipur).

Specimens examined: 02.iv.2003, Saramati ridge to Base camp area, coll. S. Panda s.n. (CAL).

(xxiv) $\boldsymbol{R}$. dalhousii Hook. f.: Corolla funnelcampanulate, white with pinkish tinge. Habit-treelet up to $1 \mathrm{~m}$ high. Habitat - growing along moist rocky slopes. Field status - common.

Distribution: India (Darjeeling in West Bengal, Sikkim and Arunachal Pradesh), Nepal; Bhutan and China (southeastern Xizang).

Specimens examined: 02.iv.2003, Saramati ridge to Base camp area, coll. S. Panda s.n. (CAL).

(xxv) R. griffithianum Wight: Corolla snow white. Habit - treelet up to $2 \mathrm{~m}$ high. Habitat - growing along moist rocky slopes. Field status - threatened (observed 3 plants only along ridge and its vicinity).

Distribution: India: Eastern Himalaya (Sikkim, Darjeeling in West Bengal, Arunachal Pradesh) and northeastern India (Nagaland), Nepal, Bhutan and southwestern China.

Specimens examined: 02.iv.2003, Saramati ridge to Base camp area, ca. $3100 \mathrm{~m}, \mathrm{~S}$. Panda s.n. (CAL).

(xxvi) R. kendrickii Nutt.: Corolla scarlet red. Habit - treelet up to $3 \mathrm{~m}$ high. Habitat — growing along moist rocky slopes. Field status - threatened.

Distribution: India: Eastern Himalaya (Arunachal Pradesh) and northeastern India (Nagaland), Bhutan and western China.

Specimens examined: 02.iv.2003, Saramati ridge to Base camp area, ca. $3100 \mathrm{~m}$, coll. S. Panda 30897 (CAL).
E. Alpine region (3300-3841 m): It includes above Base camp area up to the peak.

(xxvii) Cassiope fastigiata (Wall.) D. Don: Vegetative. Habit—decumbent dwarf shrub up to $0.1 \mathrm{~m}$ high, often growing in tufts. Habitat-growing along moist alpine rocky slopes. Field status-common.

Distribution: India (Darjeeling in West Bengal, Sikkim, Arunachal Pradesh \& Nagaland), Nepal, Bhutan and China (southeastern Xizang).

Specimens examined: 02.iv.2003, Saramati peak, $3700 \mathrm{~m}$, coll. S. Panda s.n. (ASSAM).

(xxviii) G. trichophylla Royle: Vegetative. Habitprocumbent mat-forming dwarf shrub up to $0.1 \mathrm{~m}$ high. Habitat - growing along moist alpine rocky slopes. Field status - common.

Distribution: India: Himalayas (Jammu \& Kashmir, Himachal Pradesh, Uttaranchal, Sikkim, West Bengal and Arunachal Pradesh) and northeastern India (Saramati peak of Nagaland), Pakistan, Nepal, Bhutan, southwestern China and northern Myanmar.

Specimens examined: 02.iv.2003, Saramati peak, 3700m, coll. S. Panda s.n. (ASSAM).

(xxix) R. lepidotum Wall. ex G. Don: Corolla greenish-white. Habit—Dwarf shrub up to $0.3 \mathrm{~m}$ high. Habitat—growing along moist alpine rocky slopes. Field status - common.

Distribution: India: Himalaya (Jammu \& Kashmir, Himachal Pradesh, Uttarakhand, Sikkim, Darjeeling in West Bengal and Arunachal Pradesh) and northeastern India (Nagaland), western Pakistan, Nepal, Bhutan, southwestern China and northeastern Myanmar.

Specimens examined: 02.iv.2003, base Camp to Saramati peak, ca. 3500m, S. Panda 30896 (CAL).

(xxx) R. anthopogon D. Don: Flower buds light yellow. Habit - dwarf shrub up to $0.3 \mathrm{~m}$ high. Habitat—growing along moist alpine rocky slopes. Field status - common.

Distribution: India: Himalayas (Uttarakhand, Sikkim, Darjeeling in West Bengal and Arunachal Pradesh) and northeastern India (Nagaland), Nepal, Bhutan and southwestern China.

Specimens examined: 02.iv.2003, base Camp to Saramati peak, c. 3500m, coll. S. Panda s.n. (CAL). 


\section{REFERENCES}

Anonymous (2009). A Users' Guide to the IUCN Red List Website version 1.0 (March 2009) <www.iucnredlist.org>.

Bor, N.L. (1936). A Trans-Frontier Tour in the Naga Hills. Indian Forester 62: 69-79.

Changkija, S. \& Y. Kumar (1997). Forest types of Nagaland and its floristic elements. Higher Plants of Indian Subcontinent 6: 127-141.

Hynniewta, T.M. (1994). Botany of Mt. Saramati and its environs. Bulletin of the Botanical Survey of India 36 178-188.

Mabberley, D.J. (2008). Mabberley's plant-book: a portable dictionary of plants: utilizing Kubitzki's The families and genera of vascular plants (1990) and current botanical literature, arranged according to the principles of molecular systematic. $3^{\text {rd }}$ Revised Edition. Cambridge University Press, Cambridge, 313pp.

Panda, S. (2008). Taxonomic Revision of Some Selected Genera of Ericaceae in India. PhD Thesis. Submitted to Vidyasagar University, Midnapore, 294pp.

Panda, S. \& M. Sanjappa (2008). A New Species of Vaccinium L. (Ericaceae) from India. Bulletin of the Botanical Survey of India 50: 1-8.

Vie, J.-C., C. Hilton-Taylor \& S.N. Stuart (eds.) (2009). Wildlife in a changing World - An Analysis of the 2008 IUCN Red List of Threatened Species. Gland, Switzerland, 180pp. 